\title{
Chasing Remarkable Lives: a Problematization of Empowerment Stories for Girls
}

\author{
Persiguiendo vidas para ser contadas. Una problematización de \\ las historias de empoderamiento para niñas
}

\author{
Perseguint vides per a ser contades. Una problematització de les \\ històries d'empoderament per a xiquetes
}

\author{
Macarena García-González. Pontificia Universidad Católica de Chile. \\ mgarciay@uc.cl.
}

https://orcid.org/0000-0001-8051-9969

\begin{abstract}
This article explores the question of how to assess children's literature as feminist. Drawing upon a revision of the concept of postfeminism as a gendered neoliberalism that cultivates the 'right' disposition for succeeding in a neoliberal society, I bring together two possible objects of study upon which I outline some problematic aspects. I begin by focusing on a publishing phenomenon of the last few years: the biography compilations, such as the crowdfunded Good Night Stories for Rebel Girls, that, in a more or less explicit manner, aim to provide younger generations with new repertoires of gendered agencies. Then I analyze two picturebooks that have been recommended by reading promotion agencies and praised for their anti-sexist values: Tirititesa and La bella Griselda. In both these picturebooks, we find two protagonists tran sgressing gender norms and heteronormative ideals of romantic love. Yet, I argue that they reproduce systems of exclusions that are quite problematic if read from feminist intersectionality. The texts analyzed are modeled by a postfeminist sensibility in which a celebratory "girl power" is put forward, while obscuring how (gendered) exclusions work.
\end{abstract}

Key words: postfeminism, biographies, inequalities, intersectionality, picturebooks

\section{Resumen}

Este artículo explora la cuestión de cómo celebramos a un texto como feminista. Partiendo del concepto de posfeminismo como una forma generizada de neoliberalismo que cultiva disposiciones correctas para tener éxito en una sociedad neoliberal, conjugo aquí dos posibles objetos de estudio que analizo en sus aspectos problemáticos. Comienzo haciendo foco en un fenómeno editorial de los últimos años: las compilaciones biográficas, tales como Cuentos de buenas noches para niñas rebeldes, que de una forma más o menos explícita buscan proveer a las nuevas generaciones de nuevos repertorios de agencias generizadas. Luego hago foco en dos libros-álbum recomendados por 
agencias de promoción de la lectura y celebrados por sus valores anti-sexistas: Titiritesa y La bella Griselda. En ellos encontramos dos protagonistas que transgreden las normas de género y los ideales heteronormativos del amor romántico, aunque, como argumento aquí, reproducen complicadas exclusiones. Los textos aquí analizados son examinados como productos de una sensibilidad postfeminista en la que una cultura celebratoria del "girl power" oscurece como los sistemas de exclusiones (generizadas) operan.

Palabras clave: posfeminismo, biografías, inequidades, interseccionalidad, libros-álbum

\section{Resum}

Aquest article explora la qüestió de com identifiquem un text com a feminista. Partint del concepte de postfeminisme com una forma generitzada de neoliberalisme que conrea disposicions correctes per tenir èxit en una societat neoliberal, conjugue aquí dues possibles objectes d'estudi que analitze en els seus aspectes problemàtics. Comence tot focalitzat en un fenomen editorial dels últims anys: les compilacions biogràfiques, com ara Contes de bona nit per a nenes rebels, que d'una forma més o menys explícita busquen proveir a les noves generacions de nous repertoris d'agències generitzades. Després analitze dos llibres-àlbum recomanats per agències de promoció de la lectura i celebrats pels seus valors antisexistes: Titiritesa i La bella Griselda. En ells trobem dos protagonistes que transgredeixen les normes de gènere i els ideals heteronormatius de l'amor romàntic, tot i que, com a argument, reprodueixen altres ideals normatius i injustícies estructurals. Els textos ací analitzats són examinats com a productes d'una sensibilitat postfeminista en la qual una cultura celebratòria del "girl power" enfosqueix com els sistemes d'exclusions (generitzades) operen.

Paraules clau: postfeminisme, biografies, iniquitats, interseccionalitat, llibres-àlbum

\section{Introduction}

In Space, Time and Perversion, Elizabeth Grosz poses the following questions: "By what criteria can we say a text is feminist, or feminine? How is a feminist text to be distinguished from the patriarchal or phallocentric mainstream within which we locate it and where it finds its context?" (Grosz, 1995, p.10). Grosz wrote about these concerns during the mid-90s, shortly after Judith Butler had unsettled the foundations of feminist theory with Gender Trouble (1990). Butler's work accuses the feminist movement of being complicit in the reproduction of the heterosexist setup. From these writings, Grosz outlines four potential approaches that attempt to simplify the matter: 1) attentiveness to the author's sex, 2) attentiveness to whether the content of the text includes any substantive reflections on the normativity of gender, 3) attentiveness to the readers (and the possibility of feminist appropriations of patriarchal texts) and lastly, 4) attentiveness to the style and manner of the text in its formal aspects. More specifically, 
examine stylic choices that would open up possibilities of knowing that are distant or alternative to the masculine ways of categorizing and describing ${ }^{1}$. Grosz concludes that these four approaches fall short when trying to label a text as feminist. Consequently, she proposes three other dimensions to consider: first, how it is that texts make visible the patriarchal norms and conditions in which they come to exist; secondly, whether the text problematizes the standard masculine condition from which the locus of the author is traditionally occupied, and lastly, whether the text facilitates the production of alternative discursive positions that allow to amplify and resist the limits in the regulations for the circulation of texts.

From the publication of Grosz's essay until the present time, we have bared witness to a quasi global awakening on gender inequalities. Judith Butler has become an internationally recognized intellectual. Shortly after these publications, conservative groups coined the term "gender ideology"2 . The demonstrations for March the 8th, International Women's Day, summoned up multitudes of feminist minded people in different cities around the world. For the past quarter of a century, gender inequality has become one of the main focuses of public policy. More recently, there has been an attempt in public policy and social sciences research to quantify the gap in the access to power between men and women.

Gradually the conversation has become denser, by the hand of approaches such as Caroline Criado-Pérez's Invisible Women: Exposing Data Bias in a World Designed for Men (2017). This work traverses how the world has been studied, known, and designed to men's tailoring. At the start of Covid19 crisis, female medical workers of the National Health Service in Great Britain reported and denounced that "unisex" suits, masks, and gloves laid flat on them and increased their odds of contagion (The Guardian, 2020). Tailored to the measurements of a standard male,

1 This last category appears to be the best suited to contemporary discussions on the matter. It is close to what Nelly Richard (2004) calls the "feminization of writing" produced "each time a poetic or erotic sign exceeds the retaining/containing frame of masculine signification with its rebellious surpluses" (eg. body, libido, enjoyment, heterogeneity, multiplicity, etc.) to interrupt hegemonic discourse.

2 The term "gender ideology" (ideología de género) is used by conservative groups in Spanishspeaking countries to refer to the advancement of feminism and gender theories. The term draws upon the negative connotations that have adhered to the term ideology in an effort to refer to the advancements and conceptualizations of feminism as distant from reality principles given by differences that are understood as natural. The term crystallized through its use by conservative groups during Judith Butler's visit to Brazil in 2017 that demanded the cancellation of her conference and attacked her in the airport with banners claiming that she would go to hell. The opposing term, at least from the stance of public policy, is "gender perspective" (perspectiva de género), and refers to taking into account gender inequities in the different instances of social production. In 2018, with Claudia Matus, leading researcher of the Anillos "The Production of the Gender Norm" project, we decided to use the term "opposite genders ideology" to state that while there is an implied ideology in understanding the structural conditions that have given more power to men, there is also an ideology in upholding the male/female binary for the benefit of some. Until now, we have only used the term in interviews and in this footnote. 
the suits increased their chances of becoming infected. The female medical workers concerns were featured on different news media outlets giving rise to debates that harken back to what some feminist authors have been warning us against for decades: that the world is tailored to the measure of a specific kind of man: white, able, cis-gender, heterosexual and educated. One of the authors that wields this perspective is Sylvia Wynter, a Jamaican essayist who writes about an ethnic class (White) that rules the world. Wynter capitalizes Man in her writing to bring attention to how historically - from the encounter with the so-called "New World" and all the way through the advent of the capitalist bourgeoisie in the XIX century-a group of White Western men became the measurement of the human (Wynter, 2003). In the last decade, social feminist movements have managed to install the notion of a masculine hegemony: the patriarchy.

Overthrowing patriarchal rules has been the banner of young feminist activists around the

In this article, I am interested in thinking how Gill and McRobbie's postfeminism can be linked to cultural discourses for present childhoods, especially when they take on a "girl power" narrative of empowerment for girls world. Feminist extensions and activists, or, according to media depictions of iceberg-shaped feminist groups whose top portion would reflect the \#metoo movement, viralized at the end of 2017. Particularly noted in showbusiness, the \#metoo movement is referred to as a turning point for the discourses on gender inequity. The \#metoo movement gained widespread traction because it was embraced and rendered desirable by high-power corporate women and celebrities. Thanks to liberal feminism, this collective, global movement managed to draw attention to shared experiences of sexual abuse and harassment (Banet-Weisner et al, 2020). The \#metoo movement gave a turn to what feminist theorists labeled "postfeminism", a discoursive moment in which the struggles of the 70s and 80 s were thought of as conquered, upholding the view that women's access to positions of power was dependant only on their own will to do so. As explained by Angela McRobbie and Rosalind Gill (McRobbie, 2007; Gill, 2017), within the postfeminist paradigm of the turn of the millennium, the ideas of liberty and freedom of choice were inextricably tied to the category of young women. In this article, I am interested in thinking how Gill and McRobbie's postfeminism can be linked to cultural discourses for present childhoods, especially when they take on a "girl power" narrative of empowerment for girls. In this respect, I delve into narratives that promise girls that they should and will reach spaces of power and liberty of choice that neither their mothers nor grandmothers had (Favaro \& Gill, 2019). 


\section{Measuring inequity}

In "Award and Gender," published in The Wave in the Mind: Talks and Essays on the Writer, the Reader, and the Imagination (2004), fiction writer Ursula K. Le Guin inquires how it has come to be that the majority of book prizes are awarded to men, despite the fact that most of the contending books are written by women. In her text, whose original version was distributed as a pamphlet in Seattle's Book Fair in 1999, the author delves into how either mostly male or mostly female panels of judges (the latter being scarcer) tend to choose more men as the recipients of their awards. Among Literature Nobel Prizes, the ratio is 10 to 1 , a breach that prevails in other prizes like the Newbery for young adult fiction (3 to 1), the Pulitzer for literature (5 to 1 ), or the Booker Prize (2 to 1 ). Le Guin's figures are from the 90 s, and in the more than 20 years that set us apart from her text, the Nobel has included six new female writers, which indeed improves the previous rate, yet it is not enough: we still do not have gender parity.

The urge to measure the gap between the places destined for male and female authors in the literary field may be another trap in which binary orders are produced. In Cómo se construye una autora: algunas ideas para una discusión incómoda [How a female author is built: some ideas for an uncomfortable discussion (2020)], Chilean literary scholar Lorena Amaro examines the new configurations of the Chilean literary arena and extends an invitation to review the particular figure of female authors who seek a higher visibilization of their individual personas as opposed to that of their writings (or the influences and genealogical relationships with female authors that came before them, for that matter). Amaro's opening question in the text probes how alternative feminist configurations of authorship and the creative may look like if we break from traditional ideas on authorship and its drive as a transactional brand in a market economy.

In a similar way, research on gender in the field of children's literature has mostly versed on how texts lack enough feminine figures and camp out stereotyped representations of feminine characters (see, among others, the works of Colomer and Olid, 2009; Crisp and Hiller, 2011; Trites, 2017; Koss, 2015; Mínguez-López, 2019). Interest in matters of female authorship seems rather absent, as does the discussion around the circulatory conditions of texts in a field which, although feminized - childhood appears in the domain of the feminine- follows the patterns of the rather patriarchal setup of the adult literary field.

In a dual corpus review of books published originally in Spanish and recommended by influential children and young adults' book selection committees, Xavier Mínguez López and I separately attempted to examine and understand how the production of notions of difference took place within these aesthetic artifacts. With this goal in mind, we included the variable of "gender", 
alongside ethnicity, ability, age, in order to analyze which modes of narrating predominated. We took into consideration the recommendations of six institutions that carry out consistent book selecting work for young readers: the Canal Lector platform (from Germán Sánchez Ruipérez foundation), based in Spain but with contributions from institutions in Chile and Mexico; Fundalectura from Colombia, Banco del Libro from Venezuela, IBBY from Mexico, Fundación Cuatrogatos from the USA, and the White Ravens Honor List, compiled by the prestigious International Youth Library in Munich, Germany. In the first stage, we assembled a list of more than a thousand titles which had been recommended during the 2009 to 2015 period. We then considered purely those picturebooks that had been featured on the recommendation lists of at least two of the previously identified institutions. Our final corpus consisted of 99 books published in Spain, Mexico, Chile, Colombia, Argentina, and Venezuela. 47 books had been written and/or illustrated by men and 31 by women ( 21 were the outcome of collective authorship by at least one of each). When studying the gender demographics of the protagonists, the numbers were not promising: 38 of them were male- boys, adults or malecoded animals - and 20 of them were female-coded The remaining books featured protagonists of both sexes, and at least in our analysis, characters whose gender identity lied outside of the binary were absent. These figures may convey a lack of presence of women's creative work and lack of repertoires of female agency, even when we are careful to take them to represent gender perspectives. Focusing our analysis on the plot, we found that the stories reproduced the topics of passivity and emotionality-common place topics when grappling with ideas about women and girls. Female-coded characters were featured focusing on care; they were intuitive, delicate, and good companions. The few cases in which those motifs were transgressed- which I will review further on - give us a great deal to ponder on the limits of what is currently identified as a progressive narrative in relation to gender, and its enclosure within particular feminist frameworks.

In this article, I explore the question of how to read a children's literary text as feminist through two possible objects of study. I begin by focusing on an editorial phenomenon of the last few years: the biography compilations that, in a more or less explicit manner, aim to provide younger generations with new life models and the hope of overcoming the domination of male agencies. I open by analyzing two nonfiction works showcasing biographies. I then put my analysis in tension and relation with two picturebooks recommended because of how they resist gender hierarchies and posit alternative models. 


\section{“Empowerment" Stories}

In 2016, Elena Favilli and Francesca Cavallo published Good Night Stories for Rebel Girls (translated into Spanish as Cuentos de buenas noches para niñas rebeldes), a book that emerged from a Kickstarter crowdfunding campaign. This anthology of brief female biographies broke Kickstarter's record for funding in the book category, raising over $\$ 675,614$ dollars and being translated into 47 languages. In the present, Favialli and Carvallo's work has become a franchise that encompasses two biography books and has branched out into a postcard game, planners, and even posters, which can be found at supermarkets. As one might expect, the book's success was followed by a shameless mimicking editorial offer which appears to be especially relevant in the Spanish-speaking book market. Among many others, we find Las chicas son de ciencias: 25 científicas que cambiaron el mundo (Irene Cívico and Sergio Parra), El futuro es femenino. Cuentos para que juntas cambiemos el mundo (various authors) and Valerosas 1: Mujeres que solo hacen lo que ellas quieren (Penélope Bagieu).

Good Night Stories for Rebel Girls puts together 100 female biographies, each of them pagemirrored by an illustration by one of several female artists. Among the women whose biographies are part of the compendium, we can find Malala Yousafzai, Irena Sendlerowa, Maria Montessori, Marie Curie, Frida Kahlo, Virginia Woolf, Isabel Allende, Hillary Clinton, and also, as scandalous as it might seem, Margaret Thatcher and Aung San Suu Kyi ${ }^{3}$. This book was followed by a second crowdfunded tome that included another 100 women.

The production and circulation of this collection of biographies tells us a great deal about an allegedly progressive educational discourse oriented towards gender equity. Paradoxically, these books are (crowd)funded even - as if there was no formal market for them-yet they have turned into international bestsellers. The crowdfunding seems to be creating a narrative in which no one would be interested in a book with female biographies; crowdfunding appears as the logical alternative to an indifferent editorial industry, as a solution that involves grassroots efforts and collective (consumer) actions. The authors call their supporters and readers 'rebels' (a monicker that is repeated in the title of both volumes): the union of forces would make possible to voice stories that otherwise silenced. Most reviews advocated this book as an alternative to princess stories; there are some cases in which the collection is directly mentioned

\footnotetext{
${ }^{3}$ Burmese polititican which ascended to the office of State Counsellor (similar to prime minister). She has been severly critized for Myanmar's inaction in response to the genocide of the Rohingya people. In 2019, Suu Kyi appeared in the International Court of Justice where she defended the Burmese military against allegations of genocide against the Rohingya.
} 
as an alternative to the Disney princess universe. But I would be inclined to think that this is not very far from Disney's appropriations of feminism: the ideal of an empowered and successful woman that Cassandra Stover describes as Disney's problematic postfeminism (Stover, 2013).

Shortly after the publication of Favilli and Cavallo's project, Stories for Boys Who Dare to Be Different: True Tales of Amazing Boys Who Changed the World without Killing Dragons (Brooks and Wintor, 2018) came out to the market resembling the cover design of its girl-addressed predecessor, and featuring 100 one-page male biographies, each neighbored by a full-color illustration. No reference is made to the rebel girls book, neither as a model nor as a source of inspiration, and the anthology is presented as an "inspiring collection of histories of 100 famous and not-so-famous men from the past to the present day that made the world a better place through compassion, generosity, and self-trust" (n.p.). The name list includes characters one would not necessarily consider as compassionate or generous, such as Salvador Dalí, George VI or Arthur Rimbaud. The book's back cover includes a starred disclaimer: "without action heroes or princesses to save". 'Daring' and being 'different' are then signifiers of a new masculinity that dares to (en)counter readers with a world alternative to action heroes and passive princesses. It seems that in order to educate the men of tomorrow it is of paramount importance to emphasize a 'daring' that is not a matter of heroism anymore, but rather orients itself towards difference, towards walking the untrodden paths of male generosity and compassion. Boldness for him and rebelliousness for her, perhaps because the norm weighs differently on each side of the binary.

An analysis of the similarities and differences between the two books aids in mapping the reach and limits of a well-intentioned education sensitive to gender inequity. It is already problematic that there is a distinction to be made between the stories for girls and boys, and its framing within the discourse of empowerment for younger generations. A discursive feature that stands out in both books is their inclination towards a neoliberal logic in which individuals have the ability and capacity to A discursive feature that stands out in both books is their inclination towards a neoliberal logic in which individuals have the ability and capacity to direct their life over and despite their direct their life over and despite their circumstances. circumstances Moreover, the objective of a life seems to be its orientation towards those achievements worthy of being narrated. In Good Night Stories..., the achievements of women are largely associated with notions of acknowledgment: the book's back cover presents the work as a collection of "life adventures" of "extraordinary women" to inspire girls to "dream big and reach their dreams". 
The index displays each profile next to her occupation: ranging from writers, to politicians, queens (and pharaohs), mathematicians, activists and artists of various mediums.

A thorough look at the similarities and differences between the first volume of the Rebel Girls

In Good Night Stories..., the achievements of women are largely associated with notions of acknowledgment: the book's back cover presents the work as a collection of "life adventures" of "extraordinary women" to inspire girls to "dream big and reach their dreams" and the Daring Boys would have to course along the edges of the social in these texts. For instance, the book for girls showcases some examples of collective biographies - the Brontë sisters, the Mirabal sisters, the Williams sisters, and the "cholitas escaladoras" in Bolivia - and the book for boys features only one case of this kind of biography: a group of boys in the Isca Academy in England that defy the norm by wearing skirts to go to school. The book for girls is the outcome of collective and collaborative manufacture: two authors gestated the project, thousands of "rebels" funded it, and sixty female artists were invited to make the illustrations. The version for boys, on the other hand, is cataloged as being authored by Ben Brooks with a blunt reference to Quinton Wintor's illustrations, and the scant references to biographical collectivities seem to manufacture the daring man (and present boy) as a lone actor. Now, despite the collectivity of its design, its production context, and the few entries with references to those lives that are told together, the biographies of the book for girls also dodges references to solidarity, the social, and the collective. In a fairly standard style for children's stories, most of the biographies begin with "once upon a time." The book showcases and narrates stories of women who have had to face the world by themselves (with exception given to those cases of collective biographies), by drawing from a relentless, apparently self-gestated, inner determination in order to do what they desired. There are no guides or companions. These life stories, narrated with fairy tale tropes, produce models in which girls, in order to accomplish their dreams, must ignore traditional advice and overcome social limitations. Individual rebelliousness is presented as the model to follow in all but a few occasions - such as the one of the "cholitas escaladoras", in which the rebellion is forged from a sense of community. In the book for boys, on the other hand, the repertoire of actions, attitudes, and orientations is wider and achievements are not organized only in relation to notions of success, nor in reference to alternative ways of shaping a life. Brooks seems to dodge the cultural politics of the happy ending expected from the modern fairy-tale structure. For example, we are told the sad finale of Galileo Galilei, whose research posed opposition to the church and died when he was still under arrest, as well as the horrible fate of the Pakistani boy lqbal Masih, murdered 
for opposing and resisting the owners of the carpet factories that were exploiting him. There are several alive men featured too. The British actor Daniel Radcliffe - known for impersonating Harry Potter - is featured and he is quoting saying that having people perceiving him as gay is wonderful. Through stories like these, the book for boys seems to insinuate alternative repertoires: it is not about "big dreams" anymore but about daring to be different.

An analysis of the similarities and differences between the two books aids in outlining a certain "progressist" consensus on what a gender-sensitive education is. Girls would have to learn to empower themselves, while boys would have to learn to value difference. This way, the progressivist repertoire about education on gender seems to widen the alternatives for boys, at the same time that it returns with imperatives about girls. With the latter in mind, the book for boys can be read as a deviation from what the Australian theorist Raewyn Connell (2000) calls hegemonic masculinity: the cultural dynamic that grants a place of power and leadership to the masculine and to men. The book for "rebel girls", on the other hand, seems to be oriented towards elaborating a narrative in which women would access power and spaces considered masculine, but does not invite girls to question the production of difference, the hierarchies of power, or how we produce a life worth telling. This variety of feminism, concerned with the legitimation of women's capacity, is the one that Angela McRobbie and other female authors have described as postfeminism or "girl-power feminism - a feminism that produces accomplices and aligns with consumerist and individualist values (McRobbie, 2007; Ringrose, 2007). The term postfeminism is used to show how the mainstream would use the term feminism as a best-seller title, or as a signifier fancied by celebrities (Valenti, 2014; Gill, 2017). As Gill indicates, postfeminism is not exclusive to white affluent women, even though it is oriented towards traditional notions of power and privileges the aforementioned demographic. Postfeminism is a term that describes a historical moment that is usually located around the turn of the last century but that, nonetheless, remains functional to explain the uses of feminism in transnational children's culture.

Biographies for girls can also be read as attempts to transform that biographiable life into a "happy object", as Sarah Ahmed (Ahmed 2010, 39) labels the cultural commodities that mobilize our actions on the promise of future happiness, obscuring not only any possible critiques, but also the implied surrenders that come with choosing and living

Biographies for girls, in contrast to biographies for boys, can also be read as attempts to transform a person's biographiable life into a "happy object." Sarah Ahmed (Ahmed, 2010, p.39) labels these kinds of productions as cultural commodities. They mobilize our actions on the promise of future happiness. These cultural commodities obscure not only any possible 
critiques, but also veil the implied surrender embedded with participating in certain economic lifestyles. Urging the question: to what price is each of those celebrated lives lived?

What is the painful genealogy of women's access to spaces of power? We could also read these stories from what is currently understood as liberal feminism, a paradigm in which rebelliousness is scarcely anti-systemic, and profiles itself as an assimilation to the hierarchy, only with a larger quota of women in positions of power, and more positions of power for women. The phrase of the African American tennis player Serena Williams in the book for rebel girls gives us a good reach of how ironic this epic repertoire of rebellion is: "I am fascinating. I smile a lot. I win a lot. And, plus, I am really sexy" (p. 179).

\section{Transgressions in picturebooks}

In picturebooks, the aesthetic proposals that reproduce gender are denser in their material and semiotic aspects, which may complicate the dimensions proposed by Grosz, making them further elusive: How is a feminist story narrated? Is it enough to present empowered female characters? Must there be a critique of the dominating gendered and sexual setups? How does the interplay between text and visual narration unfold? These questions are hard to tackle, and they warn us about the difficulties of carrying out a more complex analysis. As outlined previously, we usually consider gender issues in the production of children and young adult's literature in relation to the representation of sexual and gender identities (Abate and Kidd, 2011; Smolkin \& Young, 2011; Lester 2014), or in relation to the stereotyped (or emancipated) representation of their protagonists. Alternative approaches such as the analysis of ways of making the masculine (Kidd, 2003; Stephens, 2013; Pastor, 2014) or, the way mothers are depicted (Joosen, 2015) give us other entry points. In this article, I focus on protagonists that appear to be transgressive of gender norms. From the whole sample of 99 books examined by Xavier Mínguez-López and me, only two books, and only two protagonists, seemed to escape from stereotypical representations of the feminine: Griselda, in La bella Griselda [Beautiful Griselda] (Isol, 2010), and Titiritesa in the homonymous picturebook ${ }^{4}$. Both protagonists dominate their books to the point of naming them, and the two titles frequently appear in children's literature recommendation lists and are often labeled as anti-sexist. Still, their emancipatory proposal is not exempt from being problematic.

\footnotetext{
${ }^{4}$ All of the quotations from the picturebooks featured in this article are translations I have made on my own. As of today, there are no translations of La bella Griselda on the market, but there is a recent translation of Titiritesa into English by Mark W. Heslop.
} 
La bella Griselda, from the Argentinian illustrator Isol (2010), narrates the story of a princess whose beauty makes men lose their heads. The visual narrative - in a suggestive combination of four strong hues (blue, orange, black, and white) - showcases a set of skulls laying on the ground while the text ironically engages commonplace phrases like "make heads roll". For further provocation, the princess makes a habit of collecting disembodied heads. Since many of

We may make sense of this cultural object with the concept of postfeminism, since it manifests the ideals of achievement and displays discourses of overcoming difficulties without (re)thinking notions of privilege and hierarchy. her suitors are kings and princes, the surrounding kingdoms gradually become without rulers. Conjugating the counterpoints of visual and verbal narration, the picturebook produces beauty as a menacing, sanguinary attribute, a grotesque excess, which has often been associated with Silvia Ocampo's textual imaginary (Gagliardi, 2014). The fourfold palette, featuring black, white, orange and blue, cartoonish strokes, and a mismatch between pigmentation and the line seems to also warn us that this is not a story to be taken seriously. The story of Griselda does not pretend to be true, and is rather a distorted and absurd approximation to the princess/prince trope. Nonetheless, I would like to argue here that this ironic approximation is problematic. Firstly, because we know very little about how different types of irony are read by younger readers, although, something we know, or speculate about, is how they would understand it in a different way than adults do (Kummerling-Meibauer, 1999; Van der Pol, 2012). We could assume that the use of irony is an inherent risk that plays in the limits of communication with its readers. But the interpretations are indeed problematic because of the way in which the ending of the story restructures the initial understanding of it. Looking at the endings of stories can tell us a great deal about their moral teachings. Philosopher Nöel Carroll (2007) coined the term "narrative closure" to designate when stories conclude assuring readers that the character will not meet the same difficulties in the imagined future of the narrative; a sort of conclusive ending in which the world goes back to the status quo, a sort of balance, and a certain notion of good is outlined. As a form of narrative closure, the ending of La bella Griselda subverts the meaning of a deadly and menacing beauty. In order to solve the problem of her lethality, the beautiful Griselda meets a blind prince- the word ciego could have been used, however, a more pejorative term (cegatón) was chosen- due to his shortsightedness, he takes longer to perceive the "unmatched beauty of the princess". Yet, when he finally does, he too loses his head. On the next page, we are told that although the romance had been short-lived, it succeeded in leaving an imprint on the princess. This is followed by the image of the princess sitting in a chair, dressed with a mature-looking dress and a baby in her lap. "Nine months after, the princess had a baby 
with great resemblance to her", and on the opposing page: "How beautiful! she exclaimed... And that was the day in which Griselda lost her head" (Isol, n.p.). Her head rolls to the ground as the heads of her suitors had done before. The baby girl's beauty is as lethal as her mother's and makes Griselda's head roll. None of the other remaining characters seem to care about the death of Griselda. In the next double-page, we are told that the girl grows up happily in the palace.

A reading from a certain notion of feminist girl power will see Griselda as a woman that resists the trope of romantic love and has no issue with becoming a menace to men. Yet maternity manages to decenter her up to the point in which she also is beheaded. One could argue that because of her daughter's beauty; a younger and more promising beauty, Griselda loses not only her head, but her body. The mother's sacrifice is frequently described as one of the most salient dimensions of the gender norm.

The second example of a character that escapes the gender norm is, also a princess, Tiritiesa. One should consider thinking about why models of behavior labeled as "rebellious" to the gender norm in child culture are often princesses at least if we consider how Disney animated films are complicit in the creation of a child-princess culture. From Mulan's crossdressing to save her father from going to war, to braveness of Pocahontas and Merida, we do find examples of princesses that escape the mold of feminity and rebel. In the second picturebook, a princess named Titiritesa ${ }^{5}$ lives in the kingdom of Yesterday, where she likes to "gorge lumps of sugar and splash in puddles. Her father, King Tartufo, thinks this is funny, but her mother, Queen Mandolina, gets angry". This is how the story begins: with a girl that defies the mandates of her mother by eating what she is not supposed to (sugar cubes) and playing where she is not supposed to (the puddles). The queen is swiftly constructed as an antagonist, the guardian of royal decorum, while the father remains a lax and carefree. From the text, we can observe contrasting dispositions of the monarchy in the following quote, " "Titiritesa dreamed of exploring the world on a blue horse. Mandolina dreamed of seeing her daughter married. Tartufo did not dream: on his back, he would snore and snore" (unpaginated). The illustrations show the king as sitting comfortably and unbothered, drinking wine.

\footnotetext{
${ }^{5}$ An English translation of Titiritesa is available under the title Titiritess (OQO Books, 2008,
} translated by Mark W. Heslop). 
Titiritesa escapes from home on the back of a donkey and gets involved in a series of adventures that end when she meets another girl, Wendolina. After a while, they fall in love and dream of kissing each other. In the story, Titiritesa and her female lover kiss each other so much that they decide "not to leave their dream ever again". Afterward, Titiritesa and Wendolina return to the castle, wanting to inform the king of their love and their intentions of getting married. Wedding arrangements begin, and the illustration features men dressed as Victorian slaves, carrying king Tartufo, who is lying on his royal bed (Figure 1). Someone may justify the presence of slaves in the ironic tone of the narrative, but the irony does not take away from the presence of a heavily racialized image. Can a feminist text reproduce a colonial imaginary? If one examines Titiritesa (Xerardo Quintiá \& Maurizio A. C. Quarello, 2007) from an intersectional feminist perspective - the perspective raised by Black feminists to visibilize that the different axes of oppression intersect, and that the struggle of White feminists excluded models of class, race, and nationality, among others - this text results not only racist, but an agent of exclusionary systems that may hardly be considered feminist.

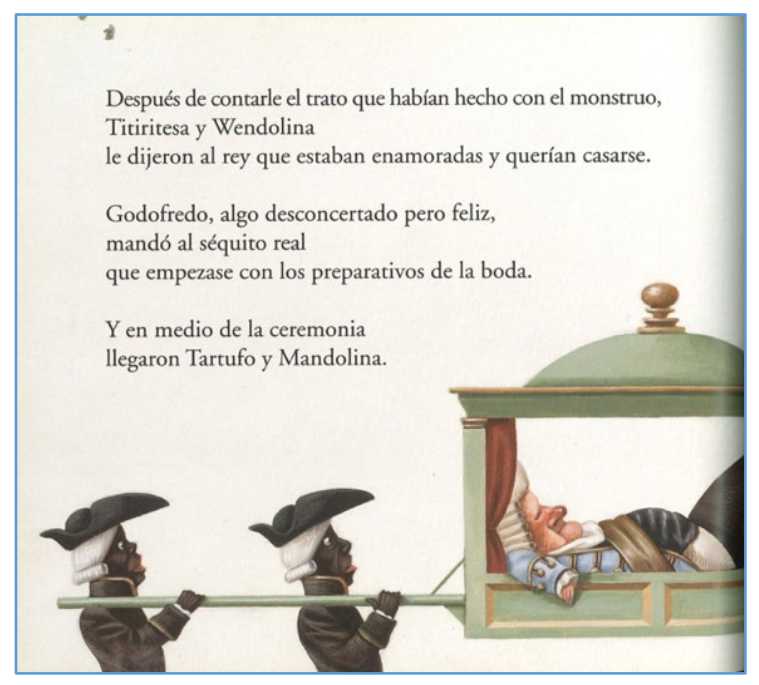

Figure 1. Titiritesa, by Xerardo Quintiá \& Maurizio A. C. Quarello, 2007, published by OQO in Spain.

We may make sense of this cultural object with the concept of postfeminism, since it manifests the ideals of achievement and displays discourses of overcoming difficulties without (re)thinking notions of privilege and hierarchy. The worldview that (re)produces notions of hierarchized difference remains untouched, and a superficial queerness is included without it implying a

The question then remains, after reading these texts, of what children's literature does with the gender norm when it attempts to undermine or subvert it. 
subversion or critique of oppressions alien to the main character. At the end of the story, and upon witnessing her daughter's marriage to a girl, queen Mandolina faints: she was the one enforcing the gender norm, and failed to do so effectively. King Tartufo, on the contrary, carries on unconcerned, enjoying his unchallenged privileges and fulfilling the trope of the easy-going yet inattentive father (resembling, among others, Merida's father in Brave).

The question then remains, after reading these texts, of what children's literature does with the gender norm when it attempts to undermine or subvert it. We examined two examples of nonfiction books for children that draw upon real-life histories as a way of offering repertoires of inspiration for the lives of readers. We then bare witness to the motion of more complex semiotic codes looking closely at two picturebooks in which the transgression of the gender norm is shown as a privilege of young and daring high-class girls. It is not as easy to suppose that when presented with stories for identification or inspiration, we fall short if the focus is merely on the character's agency as model of behavior. We also tried to read the potential of irony, of the grotesque and the hyperbolic, and how it appears to displace or deterritorialize the gender norm. We ended up bringing up a critical reading that is insufficient. What stands out in both of the reviewed picturebooks is that in the end, it might be necessary to look for (and perhaps collectively engage in the creation of) a princess tale that counters what are popularly thought of as the flaws of a princess tale: one that does not only critique idealized and domesticated portrayals of gender, but also the manifold interlocking oppressions of the social. In nonfiction histories, it might also be constructive to counter and identify the problematic presence of a certain gender rebelliousness. Thus move away from

Moreover, it appears to be crucial to examine the tacit definitions of rebellion present in cultural objects for children: what is understood by rebellion, and how is this particular understanding of the term and its praxis entangled with market economies? gender rebelliousness that appears to be disengaged from the transformation of structural conditions that (re)produce inequity and oppression, and move toward accounts that focus on fostering future models of existence that have managed to escape individual constrictions. Moreover, it appears to be crucial to examine the tacit definitions of rebellion present in cultural objects for children: what is understood by rebellion, and how is this particular understanding of the term and its praxis entangled with market economies?

This article aims to open up a critical approach to stories that are framed as feminist but appear very problematic, especially when viewed from an intersectional perspective, one in which different structural injustices and exclusions intersect. 
The texts here reviewed are often used in education with belief in their potential as anti-sexist resources, which becomes quite problematic if they are not critically addressed in the classroom (Bingle, 2018). Instead of focusing on instilling gender perspectives by presenting models of remarkable lives, I would suggest thinking gender as a problem to be addressed in all narratives and epistemological productions. Concerning inquiries over narrative fiction, it may mean a focus away from characters - and mainly from protagonists - in order to examine the narrated world and its limits. What are the possible repertoires for female and male characters in the stories we read? Why is such a binary maintained? And, more importantly, how is that we assume the gender of characters and attach possible behaviors to them when we read? We need to imagine other ways of performing gender and exploiting its multiplicity outside of dyadic paradigms and, more importantly, to imagine how the performance of gender may break out from neoliberal sensibilities that orient subjects towards the values of confidence, resilience, and individualism. In this move away from stories of what is remarkable and successful, we may need to imagine again the values of care and interdependence and how collective resistances and collaborations open new modes of entangled caring existences.

\section{References}

Abate, M. A., \& Kidd, K. B. (2011). Over the rainbow: Queer children's and young adult literature. University of Michigan Press.

Ahmed, S. (2010). The promise of happiness. Duke University Press.

Amaro, L. (2020, August 24). Cómo se construye una autora: Algunas ideas para una discusión incómoda. Palabra Pública. Recovery from https://palabrapublica.uchile.cl/2020/08/24/comose-construye-una-autora-algunas-ideas-para-una-discusion-incomoda/

Banet-Weiser, S., Gill, R., \& Rottenberg, C. (2020). Postfeminism, popular feminism and neoliberal feminism? Sarah Banet-Weiser, Rosalind Gill and Catherine Rottenberg in conversation. Feminist Theory, 21(1), 3-24.

Bingle, B. (2018). The perceived influence of children's literature on sociocultural understanding in UK Education. Journal of Literary Education, (1), 130-150.

Brooks, B., \& Winter, Q. (2018). Stories for boys who dare to be different: True tales of amazing boys who changed the world without killing dragons. Quercus.

Butler, J. (1990). Gender trouble. Feminism and the subversion of identity. Routledge.

Carroll, N. (2007). Narrative closure. Philosophical studies, 135(1), 1-15.

Colomer, T., \& Olid, I. (2009). Princesitas con tatuaje: Las nuevas caras del sexismo en la ficción juvenil. Textos de didáctica de la lengua y de la literatura. Barcelona: Editorial Graó, 14(51), 5567.

Connell, R. (2000). The Men and the Boys. Sidney: Allen \& Unwin. 
Crisp, T., \& Hiller, B. (2011). "Is this a boy or a girl?": Rethinking sex-role representation in Caldecott Medal-winning picturebooks, 1938-2011. Children's Literature in Education, 42(3), 196.

Favaro, L., \& Gill, R. (2019). 'Pump up the positivity': Neoliberalism, affective entrepreneurship and the victimhood/agency debate. In Re-writing Women as Victims (pp. 153-166). Routledge.

Favilli, E., \& Cavallo, F. (2016). Good night stories for rebel girls. Timbuktu Labs.

Flanagan, V. (2013). Into the closet: cross-dressing and the gendered body in children's literature and film. Routledge.

Gagliardi, L. (2014). El borde y los desbordes: Algunos vínculos entre las narrativas de Isol y Silvina Ocampo. VI Jornadas de Poéticas de la Literatura Argentina para Niñ@ s 19 y 20 de septiembre de 2014 La Plata, Argentina.

Gill, R. (2017). The affective, cultural and psychic life of postfeminism: A postfeminist sensibility 10 years on. European Journal of Cultural Studies, 20(6), 606-626.

Grosz, E. (1995). Space, Time and Perversion. Essays on the Politics of the Bodies. London: Routledge.

Isol \& Perrault, C. (Eds.). (2010). La bella Griselda. FCE, Fondo de Cultura Económica.

Joosen, V. (2015). “'Look More Closely,'Said Mum”: Mothers in Anthony Browne’s Picture Books. Children's Literature in Education, 46(2), 145-159.

Kidd, K. (2000). Boyology in the twentieth century. Children's Literature, 28(1), 44-72.

Koss, M. D. (2015). Diversity in contemporary picturebooks: A content analysis. Journal of Children's Literature, 41(1), 32.

Kummerling-Meibauer, B. (1999). Metalinguistic awareness and the child's developing concept of irony: The relationship between pictures and text in ironic picture books. The Lion and the Unicorn, 23(2), 157-183.

Le Guin, U. K. (2004). The Wave in the Mind: Talks and Essays on the Writer, the Reader, and the Imagination. Shambala Publications

Lester, J. Z. (2014). Homonormativity in children's literature: An intersectional analysis of queerthemed picture books. Journal of LGBT Youth, 11(3), 244-275.

McRobbie, A. (2007). Postfeminism and Populare Culture: Bridget Jones and the New Gender Regime. En Interrogating Postfeminism: Gender and the Politics of Popular Culture. Ed: Yvonne Tasker and Diane Negra. Duke University Press.

Mínguez-López, X. (2019). Intrepid or Invisible? Female Characters in Catalan Children's and Young Adult Literature. Dzieciństwo. Literatura i Kultura, 1(1), 180-205.

Pastor, B. (2014). La literatura infantil como espacio mediador en la educación de género. Raído, 8(17), 87-104.

Quintiá, X., \& Quarello, Maurizio (2007) Titiritesa. OQO.

Criado-Perez, C. (2019). Invisible women: Exposing data bias in a world designed for men. Random House.

Ringrose, J. (2007). Successful girls? Complicating post-feminist, neoliberal discourses of educational achievement and gender equality. Gender and Education, 19(4), 471-489.

Smolkin, L. B., \& Young, C. A. (2011). Missing mirrors, missing windows: Children's literature textbooks and LGBT topics. Language Arts, 88(3), 217.

Stephens, J. (2013). Ways of Being Male: Representing Masculinities in Children's Literature. Routledge. 
Stover, C. (2013). Damsels and heroines: The conundrum of the post-feminist Disney princess. LUX: A Journal of Transdisciplinary Writing and Research from Claremont Graduate University, 2(1), 29.

Sexism on the Covid-19 frontline: "PPE is made for a 6ft 3in rugby player" (2020, abril 24). The Guardian.. Recovery from https://www.theguardian.com/world/2020/apr/24/sexism-on-thecovid-19-frontline-ppe-is-made-for-a-6ft-3in-rugby-player

Trites, R. S. (2018). Twenty-first-century Feminisms in Children's and Adolescent Literature. University Press of Mississippi.

Valenti, J. (2014). When everyone is a feminist, is anyone? The Guardian, (24).

Van der Pol, C. (2012). Reading picturebooks as literature: Four-to-six-year-old children and the development of literary competence. Children's Literature in Education, 43(1), 93-106.

Wynter, S. (2003). Unsettling the coloniality of being/power/truth/freedom: Towards the human, after man, its overrepresentation-An argument. CR: The new centennial review, 3(3), 257-337.

\section{How to cite this paper:}

García-González, M. (2020). Chasing Remarkable Lives: a Problematization of Empowerment Stories for Girls. Journal of Literary Education, (3), pp. 44-61. doi: 10.7203/JLE.3.18165

** This research has been supported by ANID PIA 160007 and SOC 180023 